\title{
HUBUNGAN PENGETAHUAN IBU TENTANG ALAT PERMAINAN EDUKATIF (APE) DENGAN PERKEMBANGAN MOTORIK PADA ANAK PRASEKOLAH DI DESA PLOSOHARJO KECAMATAN TOROH
}

Oleh;

Meity Mulya Susanti. ${ }^{1}$, Christina Nur Widayati ${ }^{2)}$, Hidayatur Rozikin ${ }^{3)}$

1) Staf Pengajar STIKES An Nur Purwodadi, Email: meityms71 @ gmail.com

2) Staf Pengajar STIKES An Nur Purwodadi, Email: christina.widayati@yahoo.com

3) Mahasiswa STIKES An Nur Purwodadi, Email: annurlppm@gmail.com

\begin{abstract}
ABSTRAK
Latar Belakang: Kurangnya pengetahuan ibu tentang alat permainan edukatif akan mempengaruhi tumbuh kembang anak tidak sesuai usia mereka. Hal ini menyebabkan tidak terpantaunya pertumbuhan dan perkembangan anak. Alat Permainan Edukatif adalah alat permainan yang dapat mengoptimalkan perkembangan motorik anak. Tujuan dari penelitian ini adalah untuk Menganalisa adanya hubungan pengetahuan ibu tentang alat permainan edukatif dengan perkembangan motorik pada anak pra sekolah.

Metode: Penelitian ini merupakan penelitian studi kuantitativ dengan menggunakan pendekatan cross sectional, populasi penelitian ini adalah ibu yang mempunyai anak usia 3-5 tahun. Teknik sampling yang digunakan adalah total sampling sebanyak 40 orang. Uji hipotesis menggunakan Spearman Rank.

Hasil: Didapatkan nilai $\rho(1.000)>0.05$, maka dapat disimpulkan tidak ada hubungan yang bermakna antara pengetahuan ibu tentang permainan edukatif dengan perkembangan motorik pada anak prasekolah dan didapatkan nilai kekuatan korelasi sebesar 0.00 artinya kekuatan korelasinya sangat lemah dan arah korelasinya positif jadi kesimpulanya Ha ditolak dan Ho diterima artinya adalah tidak ada hubungan pengetahuan ibu tentang permainan edukatif dengan perkembangan motorik pada anak prasekolah.

Kesimpulan: Dari hasil penelitian ini dapat disimpulkan bahwa tidak ada hubungan pengetahuan ibu tentang alat permainan edukatif (APE) dengan perkembangan motorik pada anak pra sekolah di Desa Plosoharjo Kecamatan Toroh
\end{abstract}

Kata Kunci : Alat Permainan Edukatif (APE), Pengetahuan Ibu, Perkembangan motorik 


\section{PENDAHULUAN}

Word health organitation (WHO)

melaporkan bahwa 5-25\% anak-anak usia prasekolah menderita disfungsi otak minor, termasuk gangguan perkembangan motorik halus (Widati, 2012). Departemen Kesehatan RI Dalam (Widati, 2012) melaporkan bahwa 0,4 juta (16\%) Balita Indonesia mengalami perkembangan, baik perkembangan motorik halus dan kasar. Sedangkan menurut dinas kesehatan dalam (Widati, 2012) sebesar 85,779 (62,02\%) anak usia prasekolah mengalami gangguan perkembangan. Banyaknya negara yang mengalami berbagai masalah perkembangan anak seperti keterlambatan motorik, bahasa, perilaku, autisme, dan hiperaktif.

Angka kejadian di Amerika Serikat berkisar $12-16 \%$, Thailand 24\%,Argentina 22\%, dan Indonesia 13-18\% (Hidayat, 2010). Perkembangan motorik kasar anak yang tidak optimal bisa menyebabkan menurunnya kreatifitas anak dalam beradaptasi (Adriana, 2011). Ibu percaya bahwasebagian besar perkembangan keterampilan dan kegiatan terjadi pada usia normatif, dan sebagian besar ibu tidak mengetahui apabila penglihatan (52\%), vokalisasi $(79 \%)$, sosial tersenyum $(59 \%)$, serta perkembangan otak secara keseluruhan (68\%) dimulai di awal kehidupan anak (Ertem et al., 2007).
The National Association for The Education mendefinisikan istilah "preschool" adalah anak antara usia "toodler" (1-3 tahun) dan usia masuk kelas satu; biasanya antara usia 3 (tiga) sampai 5 (lima) tahun. Pengertian "toddler" adalah anak yang mulai berjalan sendiri sampai dengan usia tiga tahun. Anak usia TK adalah empat sampai enam tahun sedangkan anak prasekolah adalah mereka yang berusia tiga sampai lima tahun. Sedangkan Departemen kesehatan Indonesia mendefinisikan anak pra sekolah adalah anak yang berumur $36-60$ bulan (DepKes RI, 2006).

Berdasarkan studi pendahuluan yang peneliti lakukan di Desa Plosoharjo, peneliti mewawancarai 8 ibu yang mempunyai anak berusia 3-5 tahun didapatkan hasil bahwa, terdapat $3 \mathrm{ibu}$ yang tidak mengetahui tentang pengertian dan jenis permainan edukatif, terdapat 2 ibu yang mengatakan tidak mengetahui fungsi alat permainan yang disediakan di rumah bagi perkembangan anaknya, terdapat 2 ibu yang mengatakan bahwa alat permainan yang ada di rumah berbeda dengan alat permainan yang ada di tempat anaknya sekolah, terdapat 1 ibu yang mengatakan belum mengetahui alat permainan yang paling tepat untuk diberikan kepada anak usia prasekolah, terdapat $3 \mathrm{ibu}$ yang hanya memberikan alat permainan kepada anaknya dengan 
seadanya atau semampunya ibu saja tanpa memperhatikan fungsi dan manfaat alat permainan tersebut bagi anaknya. Oleh sebab itu peneliti tertarik untuk melakukan penelitian dengan judul "Hubungan Pengetahuan ibu tentang Alat Permainan Edukatif dengan Perkembangan Motorik pada Anak Prasekolah di Desa Plosoharjo Kecamatan Toroh.”

\section{METODE}

Jenis penelitian ini adalah deskriptif korelatif dengan pendekatan cross sectional dan menggunakan rancangan penelitian cross sectional melalui instrumen kuesioner. Variabel peneitian ini adalah Pengetahuan tentang permainan edukatif (independent) dan Perkembangan Motorik (dependent). Populasi pada penelitian ini yaitu semua ibu yang memiliki anak usia 3-5 tahuan di Desa Plosoharjo. Sampel dalam penelitian ini adalah 40 orang yang diambil menggunakan tehnik purposif sampling. Dengan Kriteria inklusi 1) ibu yang memliki anak usia 3-5 tahun yang tinggal di Desa Plosoharjo. 2) ibu yang memiliki anak 3-5 tahun yang bisa membaca dan menulis. 3) ibu dan anak usia 3-5 tahun dalam keadaan sehat. 4) ibu yang memiliki anak usia 3-5 tahun yang dapat berkomunikasi dengan baik.

Instrumen penelitian ini adalah kuesioner pengetahuan tentang permainan edukatif yang berjumlah 12 butir soal yang sudah diuji validitas dan reabilitas. Kuesioner penelitian ini menggunakan alternatif jawaban "benar" dan "salah", kriteria pernyataan positif (favorable) dan negative (unfavourable). Kedua peneliti menggunakan tes DDST untuk menilai perkembangan motorik.

Data yang diperoleh diolah melalui proses editing, coding, dan tabulating. Analisa data menggunakan analisa univariat untuk mendeskripsikan karakteristik rerponden dan bivariat. untuk mengetahui hubungan pengetahuan ibu tentang permainan edukatif. Uji kumputerisasi menggunakan spearman rank untuk mengetahui hubungan antar variabel .Etik penelitian mencakup : Informed Consent (lembar persetujuan), Anonimity (Tanpa nama), dan Confidentially (kerahasiaan).

Keterbatasan penelitian ini yaitu peneliti menggunakan pendekatan cross sectional, dimana metode yang digunakan hanya waktu sesaat tanpa ada cross cek ulang atau penjelasan lebih lanjut, selain itu peneliti menggunakan DDST yaitu saat anak mau di tes akan tetapi anak tersebut rewel atau masi malu-malu dengan peneliti, sehingga anak tersebut menolak saat dilakukan tes DDST. 
HASIL

\section{A. Karakteristik Responden}

\begin{tabular}{|c|c|c|}
\hline Karakteristik & $\mathrm{N}$ & Persen \\
\hline \multicolumn{3}{|l|}{ Umur ibu } \\
\hline 21-25 tahun & 6 & $15.0 \%$ \\
\hline 26-30 tahun & 15 & $37.5 \%$ \\
\hline 31-35 tahun & 7 & $17.5 \%$ \\
\hline 36-40 tahun & 12 & $30.0 \%$ \\
\hline \multicolumn{3}{|l|}{ Usia Anak } \\
\hline 4 & 19 & $47.5 \%$ \\
\hline 5 & 21 & $52.5 \%$ \\
\hline \multicolumn{3}{|l|}{ Pekerjaan } \\
\hline IRT & 15 & $37.5 \%$ \\
\hline Wirausaha & 5 & $12.5 \%$ \\
\hline Swasta & 5 & $12.5 \%$ \\
\hline Tani & 15 & $37.5 \%$ \\
\hline \multicolumn{3}{|l|}{ Pendidikan } \\
\hline SMA & 8 & $20.0 \%$ \\
\hline SMP & 16 & $40.0 \%$ \\
\hline SD & 16 & $40.0 \%$ \\
\hline \multicolumn{3}{|l|}{ Jumlah Anak } \\
\hline 1 & 26 & $65.0 \%$ \\
\hline 2 & 8 & $20.0 \%$ \\
\hline 3 & 5 & $12.5 \%$ \\
\hline 4 & 1 & $2.5 \%$ \\
\hline
\end{tabular}

\section{B. Analisa Univariat}

1. pengetahuan ibu tentang Alat Permainan Edukatif

\begin{tabular}{lcc}
\hline Pengetahuan & $\mathrm{N}$ & Persen \\
\hline Baik & 18 & $45.0 \%$ \\
Cukup & 15 & $37.5 \%$ \\
Kurang & 7 & $17.5 \%$ \\
\hline
\end{tabular}

2. perkembangan motorik

\begin{tabular}{lcc}
\hline $\begin{array}{c}\text { Perkembangan } \\
\text { motrik } \\
\text { kasar\&Halus }\end{array}$ & $\mathrm{N}$ & Persen \\
\hline Diduga & 4 & $10.0 \%$ \\
Normal & 36 & $90.0 \%$
\end{tabular}

\section{Analisa Bivariat}

\begin{tabular}{|c|c|c|c|c|}
\hline & & & Pengetahuan & Perkembangan \\
\hline & & & Ape & Motorik \\
\hline Spear & Pengetahuan & Corelation Coefficient & & 000 \\
\hline man'r & Ape & Sig (2tailed) & & 1.000 \\
\hline ho & Perkembangan & Corelation Coefficient & 000 & \\
\hline & Motorik & Sig (2tailed) & 1.000 & \\
\hline
\end{tabular}




\section{PEMBAHASAN}

Hasil uji statistik Spearman rho menggunakan komputerisasi didapatkan nilai $\rho(1.000)>0.05$, maka dapat disimpulkan tidak ada hubungan yang bermakna antara pengetahuan ibu tentang permainan edukatif dengan perkembangan motorik pada anak prasekolah dan didapatkan nilai kekuatan korelasi sebesar 0.00 artinya kekuatan korelasinya sangat lemah dan arah korelasinya positif jadi kesimpulanya Ha ditolak dan Ho diterima artinya adalah tidak ada hubungan pengetahuan ibu tentang permainan edukatif dengan perkembangan motorik pada anak prasekolah.

\section{SIMPULAN}

Berdasarkan hasil analisa data dan tujuan dalam penelitian ini, maka hasil penelitian ini adalah pengetahuan ibu tentang Alat permainan edukatif kategori baik yaitu 18 responden (45.0\%), perkembangan motorik halus dan kasar pada anak paling dominan normal yaitu sebanyak 36 anak dan yang lainya diduga, didapatkan niai $p$ value $(1.000)>0.05$ maka dapat disimpulkan tidak ada hubungan antara pengetahuan ibu tentang permainan edukatif dengan perkembangan motorik.

\section{DAFTAR PUSTAKA}

Adams. (2010). Stimulasion games: An Approach to learning.ohio: jones Publishing Company.

Adriana. (2011). Tumbuh Kembang Anak dan Terapi Bermain pada Anak. Jakarta : Salemba Medika.

Agus Sujianto. (2006) Psikologi Perkembangan, Surabaya : Rineka Cipta.

Arikunto. (2009). Manajemen Penelitian. Jakarta : Rineka Cipta.

Budiharto. (2008). Metode Penelitian Kesehatan. Jakarta : EGC.

Dahlan. (2010). Statistik Kedokteran dan Kesehatan. Jakarta : Salemba Medika.

DepKes RI. (2006). Pedoman Pelaksaan Stimulasi, Deteksi dan Intervensi Dini Tumbuh Kembang Anak. Jakarta.

Dewi dan Wawan. (2011). Teori dan Pengukuran pengetahuan, sikap, dan prilaku Manusia. Yogyakarta : Nuha Medika.

Dian Adriana. (2015). Tumbuh Kembang dan Terapi Bermain pada Anak Edisi 2. Jakarta. Salemba Medika.

Elizabeth B Hurlock. (2008). Perkembangan Anak : Jakarta Erlangga.

Fajriananda. (2008). Efektifitas Alat Permainan Edukatif Produksi bpplsp Regional 1 Dalam Peningkatan Multiple Intelligence Anak Usia Dini, (online).http://www.bpplspreglll.go. id.diakses 1Maret 2012. 
Hidayat. (2007). Pengantar Kebutuhan Dasar Manusia. Jakarta : Salemba Medika.

Hidayat. (2008). Pengantar Ilmu Kesehatan Anak Untuk Pendidikan Kebidanan. Jakarta : Salemba Medika.

Hurlock. (2007). Psikologi Perkembangan Suatu Pendekatan Pemainan. Jakarta : EGC.

Juntika.(2007). Materi Pokok Perkembangan Peserta Didik. Bandung :UPI.

Kartini Kartono. (2005). Psikologi Anak, Bandung : Mandar Maju.

Mulyati. (2005). Penggunaan Alat Permainan Edukatif : Upaya membantu Perkembangan Kognitif Anak Usia 3-6 tahun. Jakarta :Salemba Medika.

Notoatmodjo. (2010).Metodologi Penelitian Kesehatan . Jakarta :Rineka Cipta.

Nursalam. (2009). Konsep dan Penerapan Metode Penelitian Keperawatan
Pedoman Skripsi, Tesis dan Intrumen Penelitian Keperawatan . Jakarta : Salemba Medika.

Prakoso. (2009). Stimulasi Anak Usia dini (Panduan praktis Bagi ibu dan Calon Ibu). Bandung : Alfabeta.

Prasetyaningrum .(2009). Peran Orang Tua Dalam Meningkatkan Kualitas Hidup Anak. Jakarta: Yrama Widya.

Sholikah. (2014). Upaya Peningkatan Kemampuan Kogintif Dalam Permainan. Jakarta : EGC.

Soetjiningsih. (2014). Tumbuh Kembang Anak. Jakarta :EGC.

Sugioyono. (2013). Metode Penelitian Kuantitatif dan Kualitatif. Bandung : Alfabeta.

Sukamti Rini Endang. (2013). Perkembangan Motorik Yogyakarta: UNY.

Supartini. (2010). Buku Ajar Konsep Keperawatan Anak. Jakarta : EGC.

Zulkifly. (2006). Psikologi Perkembangan, Bandung : Rosdakarya 